\title{
Typical Aspects of the Granular Cell Tumor of the Oral Cavity
}

\author{
Paula Prieto-Oliveira1, Sérgio Vitorino Cardoso², Florence Zumbaio Mistro3, \\ Sérgio Kignel ${ }^{3}$, Suzana Cantanhede Orsini Machado de Sousa ${ }^{4}$, \\ Marco Túllio Brazão-Silva ${ }^{5}$ \\ ${ }^{1}$ Inter-Institutional Grad Program on Bioinformatics, University of São Paulo, São Paulo, Brazil \\ ${ }^{2}$ Department of Oral Pathology, School of Dentistry, Federal University of Uberlândia, Uberlândia, Brazil \\ ${ }^{3}$ Department of Semiology, School of Dentistry, Fundação Hermínio Ometto, Araras, Brazil \\ ${ }^{4}$ Department of Oral Pathology, School of Dentistry, University of São Paulo, São Paulo, Brazil \\ ${ }^{5}$ Department of Oral Diagnosis, School of Dentistry, School of Health Sciences, University of the State of \\ Amazonas, Manaus, Brazil \\ Email: paulaprietoterra@yahoo.com.br, cardososv@gmail.com, florencemistro@uniararas.br, \\ skignel@uol.com.br, scmsousa@usp.br, marcotullio@gmail.com
}

Received 6 August 2014; revised 5 September 2014; accepted 4 October 2014

Copyright (C) 2014 by authors and Scientific Research Publishing Inc.

This work is licensed under the Creative Commons Attribution International License (CC BY).

http://creativecommons.org/licenses/by/4.0/

\section{(c) (i) Open Access}

\begin{abstract}
Granular cell tumor (GCT) is a rare neoplasm that can occur in any part of the body, but mostly they are located intraorally. Its histogenetic origin remains controversial, but it probably arises from Schwann cells and is generally benign. The tumor is typically asymptomatic and appears as a nodule, with a relatively high predilection for the tongue. This article reports a case of a 72-yearold woman treated at the Center of Oral Diagnosis of the Fundação Hermínio Ometto Dental School. The patient presented with an asymptomatic nodule in the dorsal surface of the tongue for approximately 4 months. The patient was submitted to an excisional biopsy and histopatological examination revealed polyhedral cells with granular aspect. The immunohistochemical staining for S-100 presented strong reactivity, confirming the diagnosis of GCT. Finally, we made a concise discussion about the pathogenesis and fundamental clinico-pathological aspects of GCT making the differential diagnosis.
\end{abstract}

\section{Keywords}

Granular Cell Tumor, Mouth, Diagnosis 


\section{Introduction}

Granular cell tumor (GCT) is a rare benign neoplasm of soft tissues which most often arises in head and neck regions (50\% of cases). GCT arises at virtually any body site, but is mainly found in the subcutaneous tissue (32.6\%), followed by oral cavity (28.1\%), breast (15.9\%), larynx (7.6\%), gastrointestinal tract (4.7\%) and bronchus (3.4\%), perineum (2.4\%) and miscellaneous sites (2.9\%) [1]. Over half of head and neck lesions are found on the tongue. It is more common in females and adults, between 40 and 60 years. GCTs are thought to be of Schwann cell derivation and present a benign behavior in $98 \%$ of the cases [2] [3]. This article reports a case of benign GCT involving the tongue of a 72-year-old female patient, aiming to illustrate and discuss the presentation and origin of this disease.

\section{Case Report}

A 72-year-old faioderm woman presented at Center of Oral Diagnosis of Dental School of Hermínio Ometto Foundation complaining of an asymptomatic nodule on her tongue. It had been present for the past four months, and her medical history was irrelevant. Examination of the oral cavity evidenced a nodular lesion on the dorsum of the tongue, $1.5 \mathrm{~cm}$ in width, with a pinkish color and fibrous consistency. An excisional biopsy was performed, with clinical impression of focal fibrous hyperplasia (Figure 1).

The histopathological exam (Figure 2) revealed a lesion lined by a parakeratinized stratified squamous epithelium presenting parakerathosis and a mild acanthosis. In the lamina propria, there was a tumoral formation predominantly composed by large polyhedral cells showing a syncytial growth pattern, usually presenting eosinophilic cytoplasm and granular aspect, and variably amount of cytoplasmic hyaline globules. Nuclei were eccentrically located and presented a mild pleomorphism, mostly showing a vesicular appearance of chromatin. The cellular mass was intermingled with dense connective tissue and remnants of skeletal muscle fibers. Tumoral cells were PAS positive (diastase-resistant) and immunopositive for S-100. Surgical margins were free of tumoral cells. A conclusive diagnosis of GCT was rendered and the patient remains free of disease six months after surgical treatment.

\section{Discussion}

Despite the number of publications involving cases of GCT, its pathogenesis remains unclear. The first Brazilian case was reported in 1970 by Sequeira and colleagues using the term "myoblastoma" to describe a multicentric GCT involving bronchi, tongue and parotid [4]. Further this name was abolished due to S-100 and vimentin's positivity, as observed in the present case, favoring a neural origin of tumor cells. Other routine neural markers such p75 have also evidenced its nerve sheath differentiation [5]. On the other hand, the reason why these cells do not stain for S-100A6 protein, a form of S-100 protein found in other benign tumors of neural origin such schwannoma, neurofibroma, and palisaded encapsulated neuroma, needs to be clarified [6]. Besides the controversy

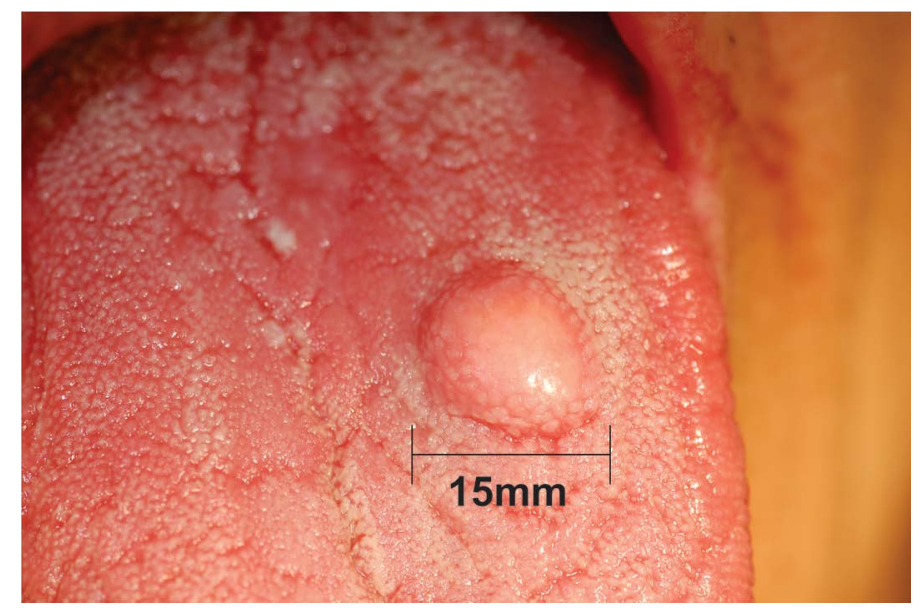

Figure 1. Clinical aspect of the lesion, showing the involvement of dorsum of tongue. 


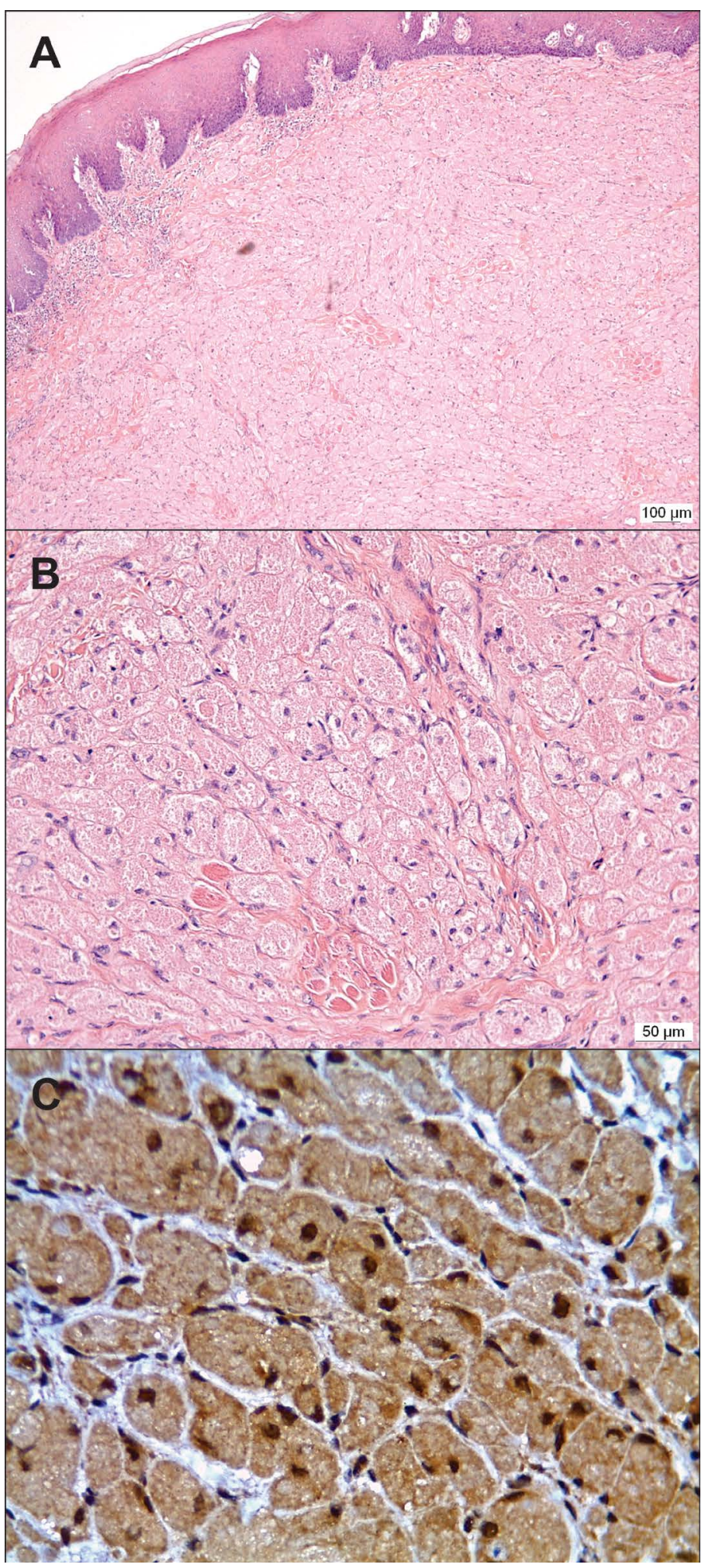

Figure 2. Histological aspects of the lesion. (A) The tumoral mass is seen next to the epithelium of tongue mucosa (hematoxylin-eosin). (B) Higher magnification showing the granular polyhedral cells containing eosinophilic granules intermingled with striated muscle fibers. (C) S-100 protein positivity of the tumor cells. 
regarding its neural origin, some authors believe that small and well-circunscribed nodules as the present case represents the true neoplasm, and lesions showing infiltrative pattern with remote satellite nodules and larger and poorly circumscribed lesions may represents a diffuse process of metabolically induced granular change of local mesenchymal cells [7]. Thus, the pathogenesis of GCT still warrants new investigations.

Clinically, GCT of the oral cavity is usually a single, sessile and asymptomatic nodule, with less than $2 \mathrm{~cm}$ in diameter, with normal or slightly pale overlying mucosa. Approximately $10 \%$ to $20 \%$ of patients may present multiple lesions [2]. A study involving 68 cases of oral GCT reported a broad age range, between 7 and 82 years, with an average age of 38.3. There was a predominance of female patients (68\%), and the tongue was the most affected site (80.8\%). About tongue lesions, $48.5 \%$ of them were in dorsal surface, as seen in this report, while $27.9 \%$ were found in lateral border and $4.4 \%$ in ventral surface. Of the remaining cases, $5.9 \%$ were on lower lip, $4.4 \%$ on upper lip, $4.4 \%$ on buccal mucosa, $2.9 \%$ on soft palate, and $1.5 \%$ on floor of mouth [7].

The GCT cells may be round, oval, polygonal or slightly elongated. The edges tend to be inconspicuous, often giving a syncytial impression. The nucleus may range from small and hypercromatic to large and vesicular, with central or peripheral location. The cytoplasm is eosinophilic and presents fine granules. Ultrastructurally, the granularity of the cytoplasm seems to represent phagocytosed lysosomes containing infolded cell membranes [8]. The cells are arranged in islets, ribbons and sheets separated by fibrous septa. The granular cells can grow along the muscle fibers and sometimes seem to fuse with them. In some cases association with nerves, may be observed. Up to $70 \%$ of cases may present contact of tumoral cells with the overlying epithelium, and in $10 \%$ of GCT there is pseudoepitheliomatous hyperplasia, which may be misinterpreted as squamous cell carcinoma [7]. Finally, positivity for PAS, S-100 protein, and NSE are typical on GCT [1] [7].

Up to $2 \%$ of GCT behave aggressively and can metastasize. A classic study reported $39 \%$ of survival rate for malignant GCT at a median interval of 3 years and $29 \%$ of patients were alive with disease [9]. Six histologic features are used distinguishing benign, atypical, and malignant granular cell tumors: 1) necrosis; 2) spindling; 3) vesicular nuclei with large nucleoli; 4) increased mitotic activity (>2 mitoses/10 high-power fields at 200× magnification); 5) high nuclear to cytoplasmic (N:C) ratio; and 6) nuclearpleomorphism. GCT that met three or more of these criteria has been classified as histologically malignant, while the presence of one or two criteria defines an atypical GCT. The isolated presence of focal polymorphism can be observed in benign tumors [9]. On the other hand, the benign histopathological picture has been also reported in clinically malignant lesions, which highlights the importance of careful clinical examination. Features such as large size, rapid growth, invasion recurrence and nodal involvement have been used to define the malignant GCT regardless of its histopathological status [10].

Other lesions which may be confused with the GCT are the congenital epulis of the newborn and the polypoid S-100-negative GCT of the oral cavity. The former is a rare but well-recognized tumor of newborns with indolent behavior, mostly occurring as soft tissue swelling of the alveolar ridges, histologically presenting a degenerative process in the way of a granular cell component [11]. It may be separated from the GCT by location, patient age, absence of cytoplasmic hyaline globules, solid growth pattern, pericytic proliferation, attenuated overlying epithelium, and negativity for S-100 protein [12]. The latter is a rare lesion identified by its polypoid appearance, lack of staining for S-100 protein and NSE, slight atypia and mitotic activity, and lack of clear expression of most markers of differentiation, and should not be mistaken with a low-grade malignancy [13].

Treatment of GCT consists of surgical excision with safety margins [14]. Local recurrence is not expected, but can occur in up to $15 \%$ of cases, probably related to incomplete removal [15].

\section{Conclusion}

In spite of rarity of GCT, this lesion must be considered in diagnosis of lesions in the dorsum of the tongue. Histopathological analysis is necessary for diagnosis confirmation and evaluation of margins. The oral lesions generally affect the tongue and prognosis is excellent.

\section{References}

[1] Wang, B.Y., Zagzag, D. and Nonaka, D. (2009) Tumors of Nervous System. In: Barnes, L., Ed., Surgical Pathology of the Head and Neck, 3rd Edition, Informa Healthcare, New York, 669-771.

[2] Weiss, S.W. and Goldblum, J.R. (2001) Enzinger and Weiss's Soft Tissue Tumors. 4th Edition, Mosby, St Louis, 1622. 
[3] Speight, P. (2005) Granular Cell Tumor. In: Eveson, J.W., Reichart, P. and Sidransky, D., Eds., World Health Organization Classification of Tumors. Pathology and Genetics of Head and Neck Tumours, IARC Press, Lyon, 185-186.

[4] Sequeira, O.F., Marcos-Martins, O., Hercules, H.C. and dos Santos, J.L. (1970) Mioblastoma múltiplo com localizacãoo brônquica, lingual e parotidiana. Hospital (Rio J), 77, 1179-1195.

[5] Rejas, R.A., Campos, M.S., Cortes, A.R., Pinto, D.D. and de Sousa, S.C. (2011) The Neural Histogenetic Origin of the Oral Granular Cell Tumor: An Immunohistochemical Evidence. Medicina Oral, Patologia Oral y Cirugia Bucal, 16, 6-10. http://dx.doi.org/10.4317/medoral.16.e6

[6] Fullen, D.R., Reed, J.A., Finnerty, B. and McNutt, N.S. (2001) S100A6 Preferentially Labels Type C Nevus Cells and Nevic Corpuscles: Additional Support for Schwannian Differentiation of Intradermal Nevi. Journal of Cutaneous Pathology, 28, 393-399. http://dx.doi.org/10.1034/j.1600-0560.2001.028008393.x

[7] Vered, M., Carpenter, W.M. and Buchner, A. (2009) Granular Cell Tumor of the Oral Cavity: Updated Immunohistochemical Profile. Journal of Oral Pathology Medicine, 38, 150-159. http://dx.doi.org/10.1111/j.1600-0714.2008.00725.x

[8] Mittal, K.R. and True, L.D. (1988) Origin of Granules in Granular Cell Tumor. Intracellular Myelin Formation with Autodigestion. Archives of Pathology Laboratory, 112, 302-303.

[9] Fanburg-Smith, J.C., Meis-Kindblom, J., Fante, R. and Kindblom, L. (1998) Malignant Granular Cell Tumor of Soft Tissue: Diagnostic Criteria and Clinicopathologic Correlation. American Journal of Surgical Pathology, 22, 779-794. http://dx.doi.org/10.1097/00000478-199807000-00001

[10] Choi, S.M., Hong, S.G., Kang, S.M., Chae, B.G., Kim, S.J., Park, P.K. and Park, H.S. (2014) A Case of Malignant Granular Cell Tumor in the Sigmoid Colon. Clinical Endoscopy, 47, 197-200. http://dx.doi.org/10.5946/ce.2014.47.2.197

[11] Regezi, J.A., Sciubba, J.J. and Jordan, R.C.K. (2011) Oral Pathology: Clinical Pathologic Correlations. 6th Edition, Elsevier Saunders, St Louis, 388.

[12] Childers, E.L. and Fanburg-Smith, J.C. (2010) Congenital Epulis of the Newborn: 10 New Cases of a Rare Oral Tumor. Annals of Diagnostic Pathology, 15, 157-161. http://dx.doi.org/10.1016/j.anndiagpath.2010.10.003

[13] Basile, J.R. and Woo, S.B. (2003) Polypoid S-100-Negative Granular Cell Tumor of the Oral Cavity: A Case Report and Review of Literature. Oral Surgery, Oral Medicine, Oral Pathology, Oral Radiology, and Endodontology, 96, 7076. http://dx.doi.org/10.1016/S1079-2104(03)00097-0

[14] Eguia, A., Uribarri, A., Gay-Escoda, C., Crovetto, M.A., Martínez-Conde, R. and Aguirre, J.M. (2006) Granular Cell Tumor: Report of 8 Intraoral Cases. Medicina Oral, Patología Oral y Cirugía Bucal, 11, 425-428.

[15] Becelli, R., Perugini, M., Gasparini, G., Cassoni, A. and Fabiani, F. (2001) Abrikossoff's Tumor. Journal of Craniofacial Surgery, 12, 78-81. http://dx.doi.org/10.1097/00001665-200101000-00013 
Scientific Research Publishing (SCIRP) is one of the largest Open Access journal publishers. It is currently publishing more than 200 open access, online, peer-reviewed journals covering a wide range of academic disciplines. SCIRP serves the worldwide academic communities and contributes to the progress and application of science with its publication.

Other selected journals from SCIRP are listed as below. Submit your manuscript to us via either submit@scirp.org or Online Submission Portal.
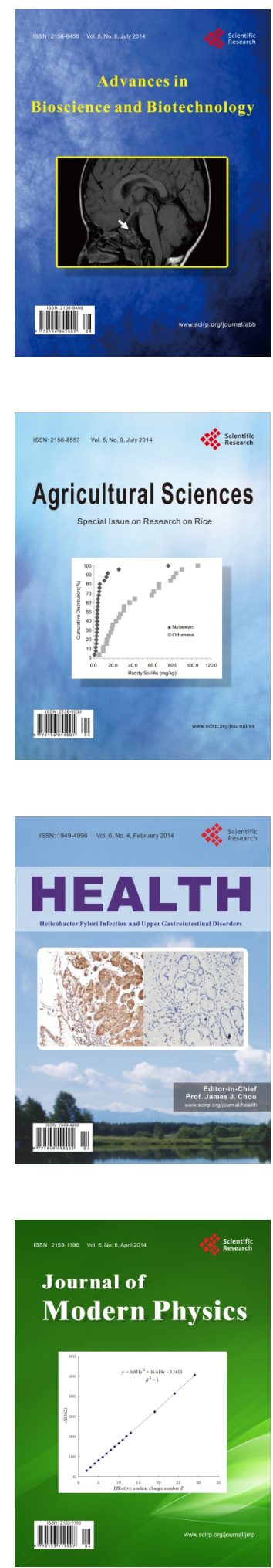
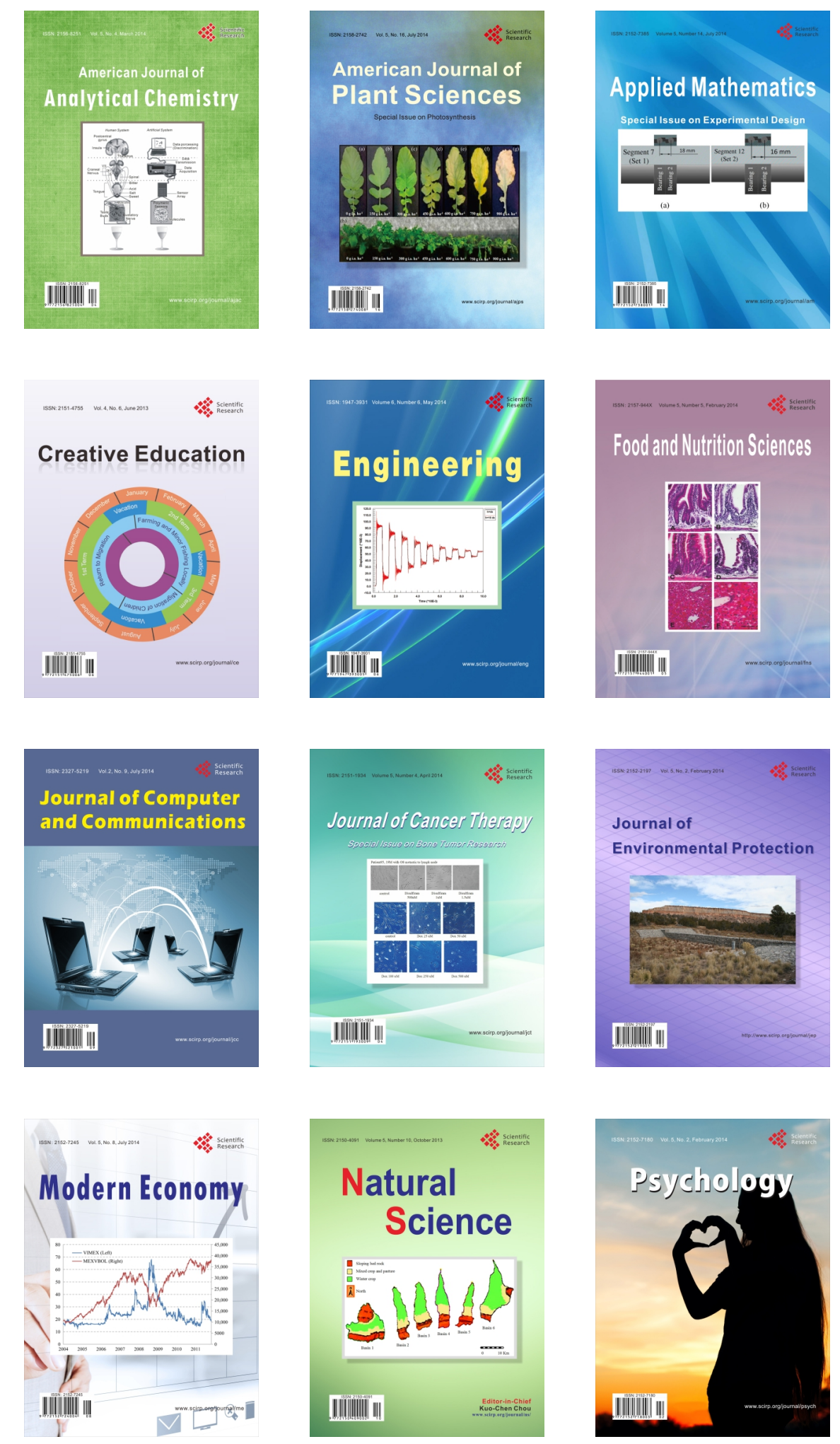